\title{
Personal expression in the high school
}

\section{E. E. Dodd}

To cite this article: E. E. Dodd (1918) Personal expression in the high school, Quarterly Journal of Speech, 4:1, 40-46, DOI: 10.1080/00335631809360644

To link to this article: http://dx.doi.org/10.1080/00335631809360644

\section{Published online: 05 Jun 2009.}

Submit your article to this journal ๘

Џ Article views: 4

Q View related articles $₫$ 


\section{PERSONAL EXPRESSION IN THE HIGH SCHOOL}

E. E. DODD

Springfield, Mo., High School

$\mathrm{T}$

WO friends, James and William, attended school together. James was the stronger student, and in some respects the stronger character, but his wonder was many times aroused on finding that William was the object of attentions and preferments that did not come to him. It finally occurred to James that his friend had an endowment which he did not possess, the capacity for being both agreeable to others and serviceable to them. While James was many times digging into the problems of mathematics and science, heedless of the world of people about him, William was alert to the real contacts of life, always ready to do more than his bit to cause the wheels of life to run smoothly. James had much interest in books and studies, William had a large interest in personal relationships. Naturally each one developed in the line of his chief interest.

Happy for himself and others is the person who by virtue of his inclination and training is a factor and force among people; and unfortunate indeed is the one who does not know how to be useful to himself and others through easy and effective associations with them. Nearly all of the relations which we esteem highly are of the personal kind. In the home, in the school, in the church, and in the thousand casual contacts of the street and shop, the relations are mostly of the personal kind, and many of the finest words in our language describe these relations. The pleasures and successes of life are bound up in, and depend upon these personal relations.

In many of our schools the senior pupil who has the highest average of classroom grades gets the valedictory honor; the one having the next highest average gets the salutatory; the valedictorian wins a scholarship to some college or university. No one of us will decry good scholarship, we all prize it, but the world places no such premium as the school does on scholarship alone. Its tests are of a saner sort. Both in the social and business life the ability of the young person to qualify well in the personal relations is of the highest importance. 
To get on successfully, the young person must have the ability to approach others cleverly, and engage them in intelligent conversation. This is what many of our best pupils, as we have always termed them, are unable to do, because their training has been so exclusively identified with books. Even in the home, the standard of judging is not that of the school, it being the child that can please and serve that takes high rank there. We shall not for a moment consider the alternative of less sound scholarship, but we do insist that our young people get development in the personal relationships, so that they shall be strong as measured by the requirements of the world, not alone those of the school.

Personal Expression seeks to give a proper understanding of the ordinary personal relations, their importance and their universal application; and it strives to give a training which leads to the best exercise of those relations.

It takes cognizance of the well-known fact that many of our students who are capable in the standard school work, are conspicuously incapable when they are brought into personal relations with others. There is a lack of personality and conversational ability in many of our pupils that is distressing to contemplate. But the schools have done almost nothing in any direct way to meet this situation. Personal Expression was organized as a course of training to meet this manifest defect in the school training. It insists that there is a personal side to every pupil that needs development, and provides a laboratory, field-work training to give it. It is mindful of the fact that it is only through the reaction of minds in actual personal experience that efficiency in the personal relations can be acquired. It furthermore holds that the reaction of minds should not be simply between pupil and teacher, but between the pupil and his fellow pupils, and between the pupil and those outside the school circle.

The two avenues through which the personal relations find their best expression are the pleasing, forceful personality and good conversational ability. These are made the primary goals of personal expression. It develops personality through the cultivation of the various personal qualities and characteristics, and it trains in conversational facility through intelligent, welldirected long-continued exercise in the art of conversation. Ini- 
tiative, poise, tact, good voice, good manners, alertness, both physical and mental, adaptability, personal kemptness, are among the elements of good personality which we seek to cultivate; and ease, skill, unity, and persistence the main elements in conversation.

The agencies employed by personal expression in developing personality and conversational ability are the following: (1) a large amount of group conversation work; (2) a large amount of field work; (3) the working out of assigned projects; (4) the study at first hand of the personality and conversational success of others; (5) the reading of the literature which relates directly to the purposes of the subject; (6) a limited number of instruction lessons.

The small conversation group is the unit for the conversational work, and to some extent the setting for the exercise of the various personal characteristics. At least one-half of all the personal expression activity turns about this unit, and the frequent changes in the conversation groups bring each pupil into personal touch with every other pupil of the class in a comparatively short time. The activities of the conversation group are so informal and cordial as to call out the fullest and best expression of which the pupil is capable. No other school agency brings pupils into such a spirit of comradeship, or the pupils and teacher into such sympathetic coöperation. In fact, comradeship and cooperation are key words in personal expression. The conversational group is ideal for leading out the timid, reserved pupils. The group is small, the setting informal, beside it is made the duty of the stronger pupils to aid the less strong. It is unfortunate that in so much of our school work the pupil must be confronted with the "I forbid." The pupil is told that he must not talk to his seatmate, he must not copy from another's notebook, he must not work out his problems or translation with others. But we have in the conversation group and in other phases of personal expression, in short in the development of the personal relations, the call for the fullest expression of the spirit of coopperation, and the full expression of the social instincts. Even boys and girls meet in the conversation groups on the basis of companionship, with no thought of the ultra-sentimental relations in their minds. 
By field work is meant all of the out-of-class-room activities which put into practice the precepts of personal expression. The associations of the school, home, church, street, and shop give abundant opportunities to work out in actual experience the varied personal relationships. The world is so full of people and their activities that there is never a dearth of field material, and when pupils are assigned this work to do, they enter into it with zest, and make good progress in it. The field work, while required, is entirely informal and self-directed by the pupil. Reports are made in class from time to time as to the pupil's progress. The boy scout keeps himself alert to find some helpful service to render each day. The spirit of the field work calls for this same alertness on the part of the pupil.

The project is a particular type of the field work in which the teacher assigns to the pupil some definite task. For example, the pupil is asked to interview a business or professional man to get his views as to the most essential qualifications in an applicant for a position; or the pupil is asked to have a talk with an old person, or with a child under ten years; or the personal expression class as a whole gives a reception to another class. The general object in the project work is to develop adaptability and resourcefulness in the personal relationships.

The other three phases of personal expression are sufficiently designated by their names. While not so important as conversation and field work, the coördinate effectively with them, and are not to be lightly, valued. The study of good personality and conversational ability in others has the same value as the study of good models in English or Art; and the reading of good books and the free classroom discussion prepare the pupil for the conversation field work aside of the subject, just as a study of the text in chemistry prepares for the laboratory phase of the subject.

But, you ask, can this result be achieved through the schools, can this personal side of the pupil be developed as we otherwise develop the pupil through school work? The answer without hesitation or reserve is in the affirmative. Recent experience has demonstrated that young people yield to training of the personal kind just as readily as to any other, and that the benefits which accrue to them are greater than those which result from much of their other school work. 
Personal Expression logically connects itself with the English Department of instruction. English teachers for years have recognized the prime importance of getting their pupils to express themselves in a free, natural, informal manner. No other agency compares with the conversation group in accomplishing this aim, and while doing so, it gives the pupil efficiency in that form of expression, namely, conversation, which he will have constant occasion to use throughout his lifetime. The development of the personal characteristics which constitute good personality, connects itself equally well with the English Department.

It may be well at this point to distinguish personal expression from oral composition and public speaking, its two nearest of. kin. The differences are fundamental. In personal expression the conservation group gives a social setting; several of the class, as many as there are groups, are talking at the same time; the work is distinctly on the cooperative basis; the timid or reserved pupil finds an easier approach to self-expression through the group exercise; the projects and field work bring the pupil into personal relations with those outside the school life; the medium of expression is conversation. The results of the training are as one could expect, very different from either the oral composition or the public speaking.

One year ago last October an experiment began in the Springfield, Missouri, High School to determine to what extent the personality and conversational ability of pupils could be developed. A section of third year English pupils, thirty in number, was selected for the experiment. Some of the pupils were excellent in their standing, a majority of them were average, and some seven or eight quite below the average. Some six or seven of these pupils were decidedly of the timid or reserved type. About forty per cent of the class were boys. The class on the whole was representative in most respects. The aims and general plan of Personal Expression were explained to the pupils of the class, who at once sensed the possibilities of the course. They readily admitted their need of the training proposed; they foresaw the benefits which would accure to them in the social and business worlds, if the experiment should prove successful, and they entered with enthusiasm into the new work. The first drive, to use a war expression, was in the interest of the personal qualities. 
How could we develop good personality if pupils continued careless and slouchy in their physical and mental attitude? Pupils must be alert, sit erect in their seats, stand erect when they stand, speak out in a good tone of voice, be ready at all times to say and do the right thing in the best way, otherwise our efforts would be vain. For eight months these pupils were under a régime of instruction and self-direction in their personal relations both in and out of school. Not more than two weeks after the work began the teacher said to me, "I notice a decided improvement in the class already, not only in the classroom, but in all their relations about the school." This improvement continued, I will add, throughout the year. When the conversational work began, the pupils were still further interested, and those of us in charge were much encouraged. Within a few weeks we knew that the experiment would succeed. Projects were assigned, and the field work set in motion. We expected to encounter difficulties, but they did not appear. The class continued twice a week till the end of the school year. At the middle of the year the other sections of Junior English voted unanimously to take Personal Expression the last half of the year, and six other high schools, including the McKinley High School of St. Louis, had the work during the same period.

I should hesitate to state to you frankly my impressions of the results achieved, if these impressions were not fully confirmed by those who were intimately identified with the work. To quote Miss Battle of the McKinley High School, "The results have been gratifying beyond my expectations." This states our experience in Springfield, the results were much better than any we had expected to see, both in the development of personality and conversational facility. Principal Miller of the McKinley High School says: "The pupils were practically unanimous in saying that it was the most interesting English class that they had ever been in." This also corresponds with our own observation. Our pupils enjoyed the work as they had never enjoyed English work before. Miss Ausherman of Springfield says: "It is a subject in which the pupils meet on the level of comrades, not rivals, all engrossed in the art of pleasing and helping each other. In my experience in teaching I have never found anything which I 
consider the equal of personal expression in the ability to draw expression from the pupils."

Another teacher, Miss Sperry, says: "I have never taught anything else which is so live and interesting, and in which I feel that I can accomplish so much."

Even at the risk of raising doubt in your minds, I will state candidly my conclusions as to the results achieved by the original class in personal expression of the Springfield, Missouri, High School. (1) The pupils showed exceptional and increasing interest in the personal expression work; (2) Their faith in its benefits increased till the close of the year; (3) I have never known a class to be so happy in any other phase of school work; (4) I have never known another class that could compare favorably with this one in the exercise of the personal qualities-the class had a personality which no ordinary high school class ever shows; (5) The progress made by the pupils in the art of conversation was excellent; (6) The facial expression shown in the conversation work was the best I have ever seen in high school pupils; (7) The timid, reserved pupils developed surprisingly; (8) The growth of the social quality of the pupils was most interesting and satisfactory.

Given an informal, social setting, with good fellowship and helpful coooperation as accompaniments; the development of the finer personal qualities and good conversational ability as the goals; pupils interested and eager to achieve the goals; all under the direction of a competent teacher-why should not the results I have enumerated naturally follow? 